\title{
Student Motives and Teaching Methods in Four Informal Adult Classes*
}

\author{
Alvin Zander \\ Program Director, Research Center for Group Dynamics, \\ University of Michigan
}

$\mathbf{M}$

ANY TEACHERS place a high value on meeting the needs of their students. At the same time they may feel the impact of forces which prevent them from fulfilling this aim to any great degree. Thus, they may ignore the motives of their pupils because persons with power require that they dispense standardized information. Or, it may be that they lack the skill to teach in such a way, or cannot "find" any motivation in their classroom members. Perhaps both they and the students feel that teacher knows best, or that teacher's interests must be followed so that the student knows the proper line at exam time. Whatever the reason, many teachers find a personal conflict centered in their desire to consider the motives and growth of their students on the one hand, and the opposing forces working against this wish on the other.

In the teaching of adults this conflict should be weaker. Adults attend school because they want to do so. Their motives must be strong to overcome the end-ofday fatigue, weather, family responsibilities and other distractions. There may be no grades to channel their varied interests into conformity, and probably few standardized courses to inhibit the ingenuity of the teacher. The adult school instructor, therefore, should be able to consider the needs of the class member much more freely, with fewer personal conflicts, and with greater satisfaction than a teacher who is in a more restricting environment.

But this expectation may not be fulfilled. It was not true in four night school classes in which we studied closely the satisfaction of student needs. We cannot generalize beyond these four classes, of course, but what we learned in observing them raises some questions about other night school groups and indicates some areas in which further study is needed. This article is a summary of part of

*Reprinted by permission from The University of Michigan School of Education Bulletin, Vol. 22, No. 7, April 1951. 
a study in the teaching of adults. The purpose of the investigation was to explore the nature of the problems in teaching adults, specifically in regard to the way in which these teachers dealt with the motives of the students.

The findings we will describe were attained by observing four courses for twelve hours each. The classes met in the high school of a middle-sized midwestern city. The observers were trained to use objective methods and recorded the frequency and nature of class participation by all class members and the teacher, as well as the teaching methods used. The teacher and the students (including those who had dropped out during the year) were individually interviewed concerning their purposes and their satisfactions and dissatisfactions with the course. These interviews occurred outside the class hours. The four courses were: Painting and Drawing, Auto Shop, Creative Writing, and World Problems. These were selected because the classes were small enough (from eight to fifteen members) to permit the teacher to know the students, and to make it possible for student-to-student interaction to occur easily. They were courses in which it was likely that the students might attend for reasons beyond information per se, and in which the teacher might have a minimum amount of obligation to adhere to a standard curriculum.

A summary of the findings must be brief here and will be presented in three areas: 1 ) the motives of the students and teachers, 2) the procedures in the classes, and 3) evidence of the fulfillment of these motives. Theoretically, these three categories correspond to the goals of the groups and the teachers, the paths followed to reach these goals, and the degree to which we perceived that they were successful in reaching these goals.

\section{Motivations}

Over two-thirds of these students attended night school for reasons other than the course content. They expected, for example, to make friends, to get away from the house, to learn something about their latent talents, or to have some kind of escape experience. However, four out of ten indicated that acquiring information was an important motivation in attending these classes. Only about ten per cent had both content and non-content motives.

The teachers recognized that many students had interests other than information. They felt that these interests were best described as "social" or "recreational" and found it difficult to further define these 
vague terms. For the most part they believed that students joined their classes to acquire information and skill. Concerning their own aims as teachers, all of them expressed a strong feeling in one way or another that they should try to meet the needs of their adult students. To do this they strove to create an informal atmosphere, they said, and to stimulate the thinking and creative efforts of their class members. They preferred a discussion method of teaching, in which there was a maximum opportunity for teacher-student and student-student interaction. They hoped, in short, to increase the opportunity for each student to get what he wanted out of the course.

Our records show that the teachers did, in fact, use the discussion method more than any other. They led the class into group discussions over forty per cent of the time observed by us. They lectured twenty-seven per cent of the time, and divided the rest among five other methods including demonstrations, administrative matters and individual work. However, some facts about the presence of discussions are of interest. During the discussions the teachers participated at the rate of almost one comment for every comment made by any student. Over half of the teachers' contributions was "giving information and ideas"; about one-quarter of the time they "questioned, prodded or evaluated". One-third of the students did almost all of the talking in each class. They directed two comments to the teacher for every one they made to a fellow class member.

Thus, even though these teachers aspired to teach in a way that was dictated by the needs of their students and described their teaching methods as those which offered a maximum opportunity for student participation, their class discussions were closer to a process in which a few students quizzed or listened to the authority. The significance of this is heightened by the following findings: 1) almost nine out of ten decisions to move to a new topic or activity were made by the teacher; 2) almost no time was spent on teacherstudent planning of course direction; 3) only one teacher inquired about the students' interests in the course and he did not use this purpose-inventory in planning the course content; 4) one class meeting was held in the home of a student, other than that almost no time was devoted to the "social interests" which these teachers felt the students had when they entered the course.

In the interviews the students were asked what they liked and 
disliked about the classes. A significant majority of them liked their fellow class members more than they liked the information content of their courses. They disliked the teaching method more than the content. The teachers told the interviewers that any difficulties they had in using effective teaching methods were directly the fault of the students. They pointed to the wide diversity in the ability of the students, their lack of ability, their unwillingness to participate, their defensiveness, or their inhibited nature. These characteristics in the persons attending their courses were seen as serious obstacles to effective teaching.

We cannot presume to judge, from data like these, whether these are good teaching methods or bad. What interests us parenthetically, is the disparity between the aims and self-described methods of these teachers and the ways in which they performed in reality. We can, however, get some indication of the adequacy of the processes used in these courses by examining the responses of the adults.

When they were asked what they were getting out of the course two persons described information they had acquired for everyone who described noninformational needs which had been fulfilled; or said they got nothing from the course. Similarly, the majority were most interested in the content and wanted more. Although a majority had wanted to learn things about themselves, make new friends or escape their mundane daily life when they entered the course, by the end of the semester they were thinking primarily in terms of the information they had obtained and relatively seldom about these unorthodox needs they had earlier felt were important.

We have already seen that there was relatively little verbal interaction among the members in the classroom. However, onethird of them said they felt that they had gained either a friend or an acquaintance with at least one person in their group. Apparently none of these friendships were very strong since an equal number said that they had not seen these friends outside of class, and, indeed, they did not plan to do so.

As the teachers reflected over what their students might say concerning what they had been getting out of the course they guessed that the students would mention most the social contacts they had made, the skills they had developed, and the stimulation their thinking had received. None of the teachers expected the students to put primary emphasis on the information they 
had learned. The teachers hoped that the students might say that they had developed new understandings, new skills and an awareness of what is good procedure in creative thinking and activity.

To sum up: A majority of students in four small night school classes had strong motivations to acquire something beyond information. The teachers said that they knew that many students had such purposes but assumed that the majority would attend for the information or skill they would acquire. They described their teaching methods as informal and intended to help the student meet his needs. The methods they actually used were not as flexible as those they described themselves as using and were probably of limited value in moving them toward the goal of meeting student needs. What the students said they were getting from the courses was primarily information and quite different from what they had hoped to get.

If the findings in these four classes are typical of any great number of others in this country, we are presented with a multisided problem. A number of questions can be posed: What should be the function of adult education classes? Should adults be "taught" in classes? Should adult courses place a higher value on the needs of their students than do other educational activities? Why did these teachers value the motivations of their students outside the classroom but find it difficult to consider them when before the students? Do we equip teachers of adults with the values and skills which make it possible for them to deal seriously with the strong and varied motives of adultlearners? In short, how shall education deal with the motives of adults when they enter an educational activity? 